\title{
Analyzing the Initiation- Response and Feedback Patterns and Its Impact on the Interaction between Teacher and Students in English Classroom
}

\section{EKA BARAHMA PUTRI ${ }^{1}$, MACHDALENA VIANTY ${ }^{2}$, AND SARY SILVHIANY ${ }^{3}$}

\begin{abstract}
This study was based on the phenomenon of classroom interaction in enhancing students' language skills in English classes using the 2013 curriculum. This study investigated the dominant initiation- response and feedback [IRF] patterns and its impact on the interaction between the teacher and the tenth-grade students during classroom spoken discourse. This qualitative research involved a teacher of English and four classes. The data were collected via classroom observations and semi-structured interviews. The findings of the study showed that in the IRF pattern, the most dominant pattern was initiation. The teacher dominated the classroom during the lesson and the IRF pattern had positive impacts on students' English when the teacher asked questions. The teacher needed to understand what questions students needed to ask to respond well because it must be in line with the 2013 curriculum, which places students at the center of learning. Teachers needed to use more various feedbacks from the IRF pattern. It can be seen from the observation that the teacher did not use feedback much when students responded to the initiation from the teacher because feedback is essential to increase student motivation, confidence, and evaluation.
\end{abstract}

\section{Keywords}

Classroom interaction, IRF pattern, students and teacher of English

\footnotetext{
${ }^{1}$ M.Pd student at Faculty of Teacher Training and Education, Sriwijaya University, Indonesia; ekabaputri@gmail.com

${ }^{2}$ Lecturer at Faculty of Teacher Training and Education, Sriwijaya University, Indonesia; Machdalena074@yahoo.com

${ }^{3}$ Lecturer at Faculty of Teacher Training and Education, Sriwijaya University, Indonesia; ssilvhiany@unsri.ac.id
} 


\section{IRJE | Indonesian Research Journal in Education | | Vol. 5 | No. 2| December|Year 2021|}

\section{Introduction}

In Indonesia, teaching English is one of the foreign languages that must be studied. The introduction of English as a second language in Indonesia has resulted in a dramatic shift in the country's educational policies (Mappiasse \& Sihes, 2014). As a result, much pedagogy related to English language education, such as methodology, curriculum, and evaluation, have gotten a lot of attention in order to improve the country's fluency with the language. It is a required topic in junior high schools for three years and senior high schools for three years (Lauder, 2008). As a result, English plays an essential role, and Indonesian students must master the language. Overall, the English language has become the de-facto standard means of communication worldwide, and Indonesia is no exception. In the period of communicative language teaching, classroom interaction has been a major concern in teaching and learning English (Sundari, 2017). Communication becomes important to improve students' ability to learn English when the teacher does a question and answer session. By communicating in the classroom, students can improve their ability in English lessons. The interaction throughout the teaching-learning process is primarily between a teacher and students, who both play a key role in the process. The classroom discourse analysis is, essentially, the type of language use (performance parole) used in classroom situations (Richard, 2002). Sinclair and Coulthard (1992) argued that they offered a three-part exchange structure: initiation, response, and feedback, which is known as IRF, in their classroom discourse model, which contained a set of hierarchically arranged ranks and levels (as cited in Paterson, 2008, p. 102). As McCarthy (2002) stated that in a discussion that is generally well-structured, it is very important to analyze patterns. Classroom discourse is closely related to the IRF pattern, which is used to analyze communication between teachers and students.

Communication between teachers and students is crucial, especially when it comes to speaking English in the classroom. It is necessary to learn English, particularly speaking English, because most agencies, firms, and the business sector want employees who are fluent in English. Abrar et al. (2018) argued that many learners, despite years of English teaching, are unable to communicate in the target language, especially in the four language skills. Speaking is one of the most difficult aspects of learning a language. All in all, communication between teachers and students must happen when teaching English in the classroom. Teaching English in the classroom is an opportunity for students to practice speaking English so that communicative practices can be produced that involve students in meaningful communication that can make students use English actively. In relation to this, Fink (2003) stated that students try to use English in the classroom even with their limitations. By examining the use of the IRF pattern in the classroom the researchers attempted to solve problems between teachers and students in initiating, responding, and giving feedback during classroom spoken discourse. Furthermore, the IRF pattern is an important aspect to see the potential for oral production in the students themselves (Liu, 2008; Lyle, 2008; Myhill,2006). Furthermore, Rashidi and Rafieerad (2010) claimed that, even though classroom discourse followed an IRF pattern in which teachers dominated a significant portion of the discussion, students initiated transactions with their teachers and 


\section{IRJE | Indonesian Research Journal in Education | | Vol. 5 | No. 2| December|Year 2021|}

frequently followed up on their teachers' answers to their questions, resulting in an IRF pattern even in student-teacher talk. It can be concluded from the result of their study that it is important for the teachers to rearrange activities to prevent a teacher-dominated classroom. In the classroom, more interaction can be fostered, such as brainstorming and problem solving, role play, stimulation, and debate.

In addition, Badr (2018) stated that bad oral production occurs in students when the teacher is trying to do the interaction, so the teacher should improve the turn by allowing them to start and analyze every interaction between the teacher and the students throughout the spoken discourse. In the Indonesia context, similar findings were also found (Rachel, 2016; Waliyani \& Yuliani, 2018; Sasmiati, 2018). In this case, there have been many studies using the IRF pattern, but rarely observe the IRF Pattern together with analyzing the effect of the IRF Pattern on students' English. The dominant part of the IRF pattern that happens during the interaction between teacher and students is examined in this study and the effect of the IRF pattern on improving students' English. In addition, some scholars have studied IRF patterns in order to determine the teacher's technique for dealing with students, analyze IRF in student group discussions, and understand the issues that develop during teacher-student interactions in the classroom, among other things. Despite the fact that many academics have previously conducted research, this study is unique, looking at IRF in classes that used the 2013 curriculum, which highlighted the idea of student-centered learning. The 2013 curriculum is applied at the research site. According to the regulation of the minister of education and culture number 70 in 2013 (reference), student-centered learning is at the core of the 2013 curriculum.

Although interaction may appear to be a straightforward task, there are numerous challenges to overcome in order to assist kids in developing their speaking skills. Menegale (2008) discovered that professors continue to dominate class discussion time. It is the most prevalent and traditional practice that occurs in the classroom during teaching and learning process. Therefore this study aims at finding out: (1). the dominant IRF Pattern in the interaction between the teacher and tenth-grade students during classroom spoken discourse at the research site and (2). the impact of IRF Pattern for the tenth-grade students during classroom spoken discourse $i$ at the research site. By examining IRF patterns as teachers and students interact in the classroom and the impact of students' spoken output of the target language, the researchers sought to gain knowledge into present interactional practices in the context of the 2013 curriculum. To reach the above goal, the researchers of this article put forward the following research question: 1. What are the dominant IRF patterns in the interaction between the teacher and the tenth-grade students during classroom spoken discourse at the research site? 2. What are the impacts of IRF Pattern for tenth-grade students during classroom spoken discourse at the research site?

\section{Literature Review}

According to Richard (2002), classroom discourse is also different in form and purpose from the language used in other contexts because students and teachers have specific social positions in the classroom and the types of activities they typically do there. The term "classroom discourse" refers to the way students engage in the classroom. The 


\section{IRJE | Indonesian Research Journal in Education | | Vol. 5 | No. 2| December|Year 2021|}

IRF model, according to McCharty (2002), is a model of classroom interaction that provides guidelines for understanding spoken language, derived from classroom interaction. The IRF pattern begins with the teacher asking a question, followed by the learner answering the question and the teacher providing feedback on the learner's response. This form of interaction, tied to students' interactions with teachers, is believed to benefit them. The learners can negotiate meaning with teachers and teachers should facilitate this interaction by confirmation checks, clarification requests, and comprehension checks (Mackey, 2012).

According to Richard and Lockheart (199), there are three types of questions; first, procedural questions, concern classroom processes and routines, as well as classroom management, rather than learning content. For example, the following questions emerged in classrooms as teachers checked that assignments were done, task instructions were clear, and students were ready for a new activity. Second, convergent questions promote students to respond in a similar way, or to respond in a way that focuses on a central issue. Short answers, such as "yes" or "no," or short sentences, are frequently used. They normally do not require students to use higher-order thinking to come up with a response instead of focusing on recalling previously delivered facts. Third, divergent questions elicit a wide range of replies from students, including those that aren't simple yes/no answers and necessitate higher-order thinking. They enable students to give their own information rather than recalling information that has already been delivered.

According to Moskowititz's flint in Brown (2001, p.170), the diversity of student responses can be seen from the six categories of student talk described as follows: First. The student response, specific: drills, reading aloud, dictation, and responding to the teacher within a precise and limited range of accessible or previously performed replies. Second, Student response, open-ended or student-initiated: students' own thoughts, opinions, reactions, and feelings in response to the teacher. Giving one of many possible answers that students have already practiced, but from which they must now choose to begin the participation. Third, silence: interactions are interrupted by pauses. There will be no verbal engagement during these periods of silence. Fourth, Silence-AV: silence in the interaction during which a piece of audio-visual equipment, e.g., a tape recorder, filmstrip projector, record player, etc., is being used to communicate. Fifth, confusion, work-oriented: because there are numerous people talking at the same time, the conversation cannot be recorded. Students are extravagantly calling out, ready to join or answer, and focused on the subject at hand. Sixth, confusion, non-work-oriented: The interaction cannot be captured if more than one person is talking at the same time. Students who are out of order, not behaving as the teacher would like, and uninterested in the task at hand. Richard and Lockheart (1996) state that Feedback can be positive or negative, and it can be used to not only let students know how well they did, but also to boost motivation and create a great classroom environment. Feedback on a student's spoken language in a language classroom might be given in reaction to the substance of what the student has produced or in the form of utterance. Several strategies can be used in providing feedback in learning content as follow:

1.) Acknowledging a correct answer: The teacher acknowledges that a student's answer is correct by saying, for example, "Good," "Yes, That's right," or "Fine."

2.) Indicating an incorrect answer: The teacher indicates that a student's answer is incorrect by saying, for example, "No, that's not quite right," or "Mmm." 


\section{IRJE | Indonesian Research Journal in Education | | Vol. 5 | No. 2| December|Year 2021|}

3.) Praising. The teacher compliments a student for an answer, for example, by saying "Yes, an excellent answer."

4.) Expanding or modifying a student's answers the teacher responds to vague or an incomplete answer by providing more information or rephrasing the answer in the teacher's own words. For example:

T: Does anyone know the capital of the United States?

S: Washington.

T: Yes, Washington, D.C. That's located on the east coast.

5.) Repeating. The teacher repeats the student's answer.

6.) Summarizing. The teacher gives a summary of what a student or group of students has said.

7.) Criticizing. The teacher criticizes a student for the kind of response provided. For example:

T: Raymond, can you point out the topic sentence in this paragraph?

R: The first sentence.

T: How can it be the first sentence? Remember, I said the first sentence is not always the topic sentence in every paragraph. Look again!

\section{Methodology}

\section{Research design, participants, and locale of the study}

This research adopted a qualitative research and used observations and interviews to gather the data of current research. The observation was chosen because this study focused on behaviorists. It was supported by Creswell (2012) about the observation. This research was conducted in Islamic school in Palembang, South Sumatera, which focused on senior high school students in grade 10 and their teacher of English. The subjects of research were Olympiad, X IPA 4, X IPA 5, X IPA 6 classes and teacher of English who taught the classes.

The research used an audio recorder, observation sheet, and interview guide as the instrument to obtain the data. The interaction between teachers and students was recorded using video recorder. The observation sheet was used by the researchers to record the data in the form of information while observing. To gather the data from the participant intensively, the interview was done. Wolcott (1994) suggested four ethnographic observation methods, one of which is to observe and record everything that happens in the classroom. Whereas the researchers were fully conscious that recording teachers' expressions and body movements was crucial since they play a significant role in controlling classroom spoken language. Such gestures and postures can only be recorded using video-recording devices; the researchers were unable to use such video-recording devices as research instruments because the teacher of English was concerned about data misuse.

As a result, the researchers decided to dismiss the teacher's anxieties and worries by going to class with an audio-tape recorder and, at the same time, writing notes about the most crucial non-verbal interactional events. In this regard, the researchers recognized that this approach was not ideal for capturing non-verbal interactional events that typically occur 


\section{IRJE | Indonesian Research Journal in Education | | Vol. 5 | No. 2| December|Year 2021|}

during classroom conversation, but the researchers believed that it was preferable than doing nothing at all.

\section{Data collection and analysis}

To answer the first study question, classroom observations were conducted to investigate teacher-student interactions. Four observations were made in four different classrooms with the same teacher of English. As a result, in this study, classroom observations were conducted with tenth-grade students in four different classrooms totaling roughly 40 students and the teacher of English who taught the classroom. The study took place between February and March, 2021. The last part of this research was to answer the second research question. Interviews were conducted with six students from different classes who had been observed. The interview techniques was semi-structured interviews where the interview was conducted to obtain the research objectives through a question and answer face to face between the interviewer and the informant and verified the data gathered from the observation.

In analyzing the data of this study, the researchers used four techniques and the data analysis is from Miles et al. (2014), as follows: (1). transcribing data; the process of transcription starts after interviews have been conducted or events have been reported. Transcription requires direct examination of knowledge by careful listening (and/or watching) repeatedly, and this is a significant first step in data analysis. (2). Data Condensation; According to Miles et al. (2014), the process of choosing, focusing, clarifying, abstracting, and/or changing the data found in the complete text (body) of written-up, field notes, interview transcripts, records, and other analytical materials is referred to as data condensation (3). The data display deals with the provision of ordered, compressed, information the assembly which allows the drawing of a conclusion. (4). Drawing and verifying conclusions; conclusions should also be tested as the analyst moves along. At this point, to establish the conclusions regarding the analysis, the data analyzed were read and re-read. The results were then double-checked by going over the data as many times as feasible.

The approach of establishing the credibility of a study and the study's expectation to acquire the best outcome from the data is known as data credibility. The researchers in this study employed the triangulation approach to demonstrate the study's trustworthiness. Creswell (2012) stated that triangulation is the process of corroborating information from multiple people (e.g., a teacher and a student), data forms (e.g., observational field and interviews). In this study, the researchers used the technique of data triangulation and reviewed the informants to examine the credibility of data.

\section{Findings}

The dominant IRF pattern in the interaction between the teacher and tenth-grade students during classroom occurred at the research site. Classroom observations were used to find out information about interactions between teachers and students. The observation was carried out twice in the Olympiad and X IPA 5 classes. The data generated were based on the interactions between teachers and students in the classroom. 


\section{IRJE | Indonesian Research Journal in Education | | Vol. 5 | No. 2 | December|Year 2021|}

Table 1. Olympiad class

\begin{tabular}{ll}
\hline IRF & TOTAL \\
\hline Types of Initiation & 7 \\
Procedural Questions & 17 \\
Convergent Questions & 15 \\
Divergent Questions & \\
Types of Response & 25 \\
Student Response, Specific & 13 \\
Open ended or student-initiated & 1 \\
Silence & \\
Types of feedback & 4 \\
Acknowledging the correct answer & 3 \\
Indicating an incorrect answer & 5 \\
Praising & 2 \\
Expanding or modifying a student's answer & 2 \\
Summarizing &
\end{tabular}

The IRF pattern had been used by teachers and students in the Olympiad class 94 times. To keep the discourse continuing, a teacher conducted 36 initiations. In this case, the teacher strikes up a conversation with the students in order to generate a positive response. The student gave the teacher an open initiation after the teacher performed a bound initiation. As a result, the teacher had to perform the necessary initiation for the students. The teacher only employed four types of initiation based on the data received from the six types of initiation. The types are procedural, convergent, and divergent questions. The questions that are more important in this observation's learning process are convergent questions, in which students were asked to answer basic inquiries regarding an option that cannot be developed. Furthermore, the total number of replies received in this study was around 44. Each student took turns responding questions from the teacher, although students were given the opportunity to answer questions first. According to the results of the responses, students had 27 responses to questions and 16 open responses. Each student had a turn to answer the teacher's questions. Every teacher asked questions, and most students could answer them properly. However, not all students wanted to react to teacher questions, as indicated by the teacher's questions, which attempted to initiate students from the questions given and called on select students to answer questions. Only a few students wanted to participate in the teaching and learning process by sharing their opinions. Finally, students should be able to participate actively in the teaching and learning process by contributing ideas and knowledge.

Based on the findings of observations and interviews, there were numerous factors why some students responded and others did not. In addition, there was a brief period of "silence" in the midst of the class when the interaction ceased. In this study's IRF pattern, there were several types of responses: student response, particular; open-ended to student-initiated; and quiet. The IRF pattern's reaction delivers the teacher's feedback to the students. Despite what can be seen from the teacher's observations, the teacher did not provide any comments during the observations in this class. The feedback that occurred in 


\section{IRJE | Indonesian Research Journal in Education | | Vol. 5 | No. 2| December|Year 2021|}

the observations was: acknowledging a correct answer, indicating an incorrect answer, praising, expanding or modifying a student's answer and summarizing.

Table 2. IRF pattern in Olympiad class

\begin{tabular}{cc}
\hline IRF & Olympiad Class \\
\hline I & 39 \\
R & 39 \\
F & 16 \\
Total & 94 \\
\hline
\end{tabular}

List of abbreviation: I: Initiation, R : Response, F: Feedback

Based on the table above, it can be determined that initiation and response is the most common turn in the IRF Pattern. When teachers initiated students, they had a positive response, but not all students responded to initiation with the teacher, despite the teacher's best efforts to include all students in the learning process.

Table 3. X IPA 5 Class

\begin{tabular}{lc}
\hline \multicolumn{1}{c}{ IRF Pattern } & Total \\
\hline Types of Initiation & 7 \\
Procedural Question & 8 \\
Convergent Question & 4 \\
Divergent Question & \\
Types of Response & 6 \\
Student Response, Specific & 5 \\
Open ended or student-initiated & 3 \\
Types of Feedback & 1 \\
Acknowledging a correct answer & 1 \\
Praising & 2 \\
Expanding or modifying a student's answers & \\
Summarizing &
\end{tabular}

The IRF pattern used 37 turns of initiation between the teacher and students. The most common IRF pattern in this class interaction was initiation. The teacher delivered many initiations to the students, but only a few of them responded appropriately. Procedural, convergent, and divergent inquiries are examples of initiation that occur during the teaching. After that, pupils gave a total of 11 turns in their responses. Students did not respond well to teacher activities, which allow the teacher to engage in more interaction. This contradicts to the curriculum, which states that the student-center should be given a priority over the teacher center. The only two answers that occurred during the learning process were specified and open-ended student responses or student initiation.

Despite the fact that not all students responded to the instructor's initiative, the teacher provided feedback based on their responses. The teacher tried to involve students even though the result was that the teacher was more dominant. This is because students did not respond, so that the feedback given was not too optimal. Some feedback occurred during teaching and learning process, namely acknowledging a correct answer, praising, expanding or modifying a student's answers, and summarizing. 


\section{IRJE | Indonesian Research Journal in Education | | Vol. 5 | No. 2 | December|Year 2021|}

Table 4. XIPA 5 class

\begin{tabular}{cc}
\hline IRF Pattern & X IPA 5 \\
\hline I & 19 \\
R & 11 \\
F & 7 \\
Total & 37 \\
\hline
\end{tabular}

The conclusion drawn from the table above was that teacher interaction continued to dominate the teaching and learning process in the classroom; students should ask more questions, but it appeared that students were not particularly active in the classroom, even the teacher's best efforts. While students just answered the questions presented by the teacher, there was no active interaction between teachers and students, and the active learning process was not carried out properly. Interviews were conducted to determine the impact of the IRF pattern on the improvement of students' English in the classroom. The point of the study was to find out how the IRF pattern influenced the students in the classroom. Teachers and students were observed to see how they interacted. Following observations in the classroom, it would be beneficial to learn the students' thoughts on the teacher's questions and responses and the teacher's feedback. According to Kotari (2004), observation is a popular method employed in behavioral science research. The researchers observed activities in the classroom during teaching and learning processes, and to confirm this conclusion, the researchers conducted interviews with several students. The observations were made to several classes: Olympiad, X IPA 5, X IPA 4 and X IPA 6 Class.

Table 5. Schedule and result of observation on $x$ class

\begin{tabular}{|c|c|c|c|}
\hline Classes & Date/Time & Teaching Materials & Results of Observation \\
\hline $\begin{array}{l}\text { Olympiad } \\
\text { Class }\end{array}$ & $\begin{array}{l}\text { Wednesday, } \\
\text { February } \\
24^{\text {th }}, 2020 \\
(9.45-10.35)\end{array}$ & $\begin{array}{l}\text { The report text about } \\
\text { animals and galaxy } \\
\text { (Komodo Dragon, } \\
\text { Birds, and Galaxy) }\end{array}$ & $\begin{array}{l}\text { The teacher explains the report texts about animals } \\
\text { and the galaxy and asks students to read the text } \\
\text { and initiates students to understand the meaning of } \\
\text { the texts and looks for the wrong pronunciation of } \\
\text { what the student reads. }\end{array}$ \\
\hline X IPA 5 & $\begin{array}{l}\text { Saturday, } \\
\text { February } 27^{\text {th }}, \\
2021 \\
(9.45-10.35)\end{array}$ & $\begin{array}{l}\text { Describing the animal } \\
\text { (Elephant) }\end{array}$ & $\begin{array}{l}\text { The teacher tells about the descriptive text about } \\
\text { animals, asks students to read the text, and looks } \\
\text { for the wrong words spoken by students who have } \\
\text { read the text. }\end{array}$ \\
\hline X IPA 4 & $\begin{array}{l}\text { Monday, March } \\
01^{\text {st }}, 2021 \\
(9.45-10.35)\end{array}$ & $\begin{array}{l}\text { Describing the animal } \\
\text { (Animal) }\end{array}$ & $\begin{array}{l}\text { The teacher tells about the descriptive text about } \\
\text { animals, asks students to read the text, and asks } \\
\text { students to look for the wrong words spoken by } \\
\text { students who have read the text. }\end{array}$ \\
\hline X IPA 6 & $\begin{array}{l}\text { March } 16^{\text {th }}, 2021 \\
(08.00-9.45)\end{array}$ & $\begin{array}{l}\text { Definition, social } \\
\text { function, general } \\
\text { structure, Identify and } \\
\text { language features of } \\
\text { song }\end{array}$ & $\begin{array}{l}\text { The teacher initiates students to read the text and } \\
\text { asks students to identify sentences from parts of the } \\
\text { song, generic structures, linguistic features of a } \\
\text { song, after one of the students reads the text, the } \\
\text { teacher initiates students' questions about the } \\
\text { wrong pronunciation when students read. }\end{array}$ \\
\hline
\end{tabular}

The table above describes the observations in the classroom such as the time and date of the observations, the subject matter, and the results of these observations. To illustrate that the IRF Pattern has an impact on improving students' English, interviews were done. Six tenth-grade students participated in the interview. 


\section{IRJE | Indonesian Research Journal in Education | | Vol. 5 | No. 2 | December|Year 2021|}

Table 6. The result of the student's interviews

\begin{tabular}{|c|c|c|}
\hline No. & Questions & Response \\
\hline 1. & $\begin{array}{l}\text { Do you like being } \\
\text { active in the } \\
\text { classroom? }\end{array}$ & $\begin{array}{l}\text { Student 1: sometimes I am also active, miss if I understand the material. } \\
\text { Student 2: Active. } \\
\text { Student 3: If the teacher asks a question, I will answer it. } \\
\text { Student 4: active if during the question session. } \\
\text { Student 5: not really. } \\
\text { Student 6: Active. }\end{array}$ \\
\hline 2. & $\begin{array}{l}\text { What do you think } \\
\text { about ma'am ria in } \\
\text { delivering the } \\
\text { material? Does she } \\
\text { directly explain the } \\
\text { material or give } \\
\text { examples? }\end{array}$ & $\begin{array}{l}\text { Student 1: ma'am ria also sometimes gives direct examples while explaining } \\
\text { the material and then giving example. } \\
\text { Student 2: There must be a delivery, right?, remember the material that has } \\
\text { been studied before then enter the new material, from the new material the } \\
\text { core lesson is explained. } \\
\text { Student 3: they are usually explained it first and then given an example. } \\
\text { Student 4: First, explain it, and then give an example. } \\
\text { Student 5: explain the material directly. } \\
\text { Student 6: Usually it is explained first after that the teacher gives questions to } \\
\text { the students. }\end{array}$ \\
\hline 3 & $\begin{array}{l}\text { What language } \\
\text { does Ma'am Ria } \\
\text { use when } \\
\text { explaining the } \\
\text { subject matter, } \\
\text { does she use } \\
\text { English or } \\
\text { Indonesian? }\end{array}$ & $\begin{array}{l}\text { Student 1: Most of them use English but there are about } 20 \% \text { maybe use } \\
\text { Indonesia, so that it can make it easier for students to understand the lesson. } \\
\text { Student 2: ma'am ria usually uses English, after that it is only translated into } \\
\text { Indonesian. } \\
\text { Student 3: sometimes uses English, if for example, a student doesn't } \\
\text { understand, then it is translated to Indonesian. } \\
\text { Student 4: sometimes also in Indonesian, sometimes in English, mixed. } \\
\text { Student 5: English, sometimes Indonesian. } \\
\text { Student 6: Use English, but if there are students who don't understand what } \\
\text { the teacher was saying, it is usually translated into Indonesian. }\end{array}$ \\
\hline 4 & $\begin{array}{l}\text { in explaining the } \\
\text { material during } \\
\text { this pandemic, } \\
\text { does ma'am ria } \\
\text { usually only speak } \\
\text { or share the } \\
\text { material in your } \\
\text { WA groups? }\end{array}$ & $\begin{array}{l}\text { Student 1: sometimes also verbally but also shared through the google } \\
\text { classroom. } \\
\text { Student 2: through google meet and also using the material in google } \\
\text { classroom. } \\
\text { Student 3: Usually through google meet or google classroom. } \\
\text { Student 4: Explain verbally from google meet after that through google } \\
\text { classroom for assignments. } \\
\text { Student 5: Both. } \\
\text { Student 6: The material from google classroom that the teacher will explain } \\
\text { through Google Meet. }\end{array}$ \\
\hline 5 & $\begin{array}{l}\text { During this } \\
\text { pandemic the } \\
\text { system uses } \\
\text { Google } \\
\text { Classroom, right? } \\
\text { So, how do } \\
\text { teachers usually } \\
\text { call out the } \\
\text { students to answer } \\
\text { questions? }\end{array}$ & $\begin{array}{l}\text { Student 1: sometimes also mentioned in the class list through absenteeism or } \\
\text { if the students understand they raise their hand. } \\
\text { Student 2: hmm.. so random.... usually called by the teacher so everyone can } \\
\text { participate in class so that all students can interact in class } \\
\text { Student 3: the teacher usually asks the student first who wants to answer the } \\
\text { question, after that if no one comes forward, then the teacher will call the } \\
\text { student to answer the question. } \\
\text { Student 4: It depends on someone who wants to answer the question, if } \\
\text { someone wants to, answer that... If there isn't one, they will be appointed. } \\
\text { Student 5: directly call the student. } \\
\text { Student 6: If the students want to answer a question from the teacher, for } \\
\text { example, "who wants to answer the question?" then if no one wants, the } \\
\text { teacher will appoint students. }\end{array}$ \\
\hline
\end{tabular}


Table 6. Continued...

\begin{tabular}{|l|l|l|}
\hline 6 & $\begin{array}{l}\text { When studying, } \\
\text { does the teacher } \\
\text { explain the material } \\
\text { first before sending } \\
\text { it to your study } \\
\text { group? }\end{array}$ & $\begin{array}{l}\text { Student 1: before the assignment is sent, it must be explained first, given... } \\
\text { first understand the material. } \\
\text { Student 2: Explained first so that students who do the assignment understand } \\
\text { what to do } \\
\text { Student 3: Explained before being given a task. } \\
\text { Student 4: It must be explained first. } \\
\text { Student 5: Explained the material first and then sent it to the group } \\
\text { Student 6: explained first. }\end{array}$ \\
\hline 7 & $\begin{array}{l}\text { In your opinion, } \\
\text { does it have any } \\
\text { effect on your } \\
\text { English when } \\
\text { ma'am ria asked any } \\
\text { questions? Is your } \\
\text { English getting } \\
\text { better? }\end{array}$ & $\begin{array}{l}\text { Student 1: My English has improved, maybe because there is a lot to learn. } \\
\text { Student 2: if it depends on the individual if puan.... it will definitely increase } \\
\text { because there will be practice immediately if not practice can't speak in } \\
\text { English for everyone. } \\
\text { Student 3: I think it's getting better. } \\
\text { Student 4: Yes, it will definitely increase because we interact with each other. } \\
\text { Student 5: it's getting better } \\
\text { Student 6: Increase }\end{array}$ \\
\hline 8 & $\begin{array}{l}\text { Then when Mam } \\
\text { Ria asks questions } \\
\text { about the lessons } \\
\text { you are studying } \\
\text { and provides } \\
\text { corrective responses } \\
\text { from your answers, } \\
\text { what kind of impact } \\
\text { does it have on your } \\
\text { English? }\end{array}$ & $\begin{array}{l}\text { Student 1 :hmm very influential, ma'am ria provides improvements if we } \\
\text { don't understand, we become more understanding about English. Maybe } \\
\text { even more, we can learn a lot from these improvements. } \\
\text { Student 2: have a positive impact. } \\
\text { Student 3: So it seems like I understand better because if it's wrong, it must } \\
\text { be corrected so that it has a positive impact. } \\
\text { Student 4: Of course it will increase. } \\
\text { Student 6: So we know more about our mistakes so we can fix them faster. }\end{array}$ \\
\hline
\end{tabular}

To see the impact of the IRF pattern on students' English, it can be seen from the students' answers about their daily routine in the classroom. These questions were asked to obtain information about whether students played an active role during the lesson. Then, the result of the first question is students play an active role in responding to the teacher. In the second question, the all six students gave the same response, stating that the teacher usually described the content first and then gave an example to focus students on the questions they wished to ask regarding the teacher's explanation. The third question is how the interaction between teacher and students occurs during English lessons whether the teacher initiated the students using English or Indonesian. It can be concluded that the teacher used English and translated it into Indonesian so that students who did not understand the teacher's orders could understand what the teacher said. The fourth question is to make sure that students did assignments from the teacher in a good way and according to the rules. This question is to find out how students interacted with the materials presented by the teacher. The fifth question, how the teacher initiated students to get the responses the teacher wanted, whether the teacher gives questions based on absenteeism, randomly, or students' wishes. Based on the results of the interviews, the teacher gave questions not only through attendance but also randomly, but before the teacher called students based on attendance, the teacher always offered students to answer questions so that students could play an active role in question 


\section{IRJE | Indonesian Research Journal in Education | | Vol. 5 | No. 2| December|Year 2021|}

and answer session. The sixth question, based on the interview results, students said that the teacher explained the material first before sending assignments to students. This is part of the IRF pattern interaction. When the teacher tried to explain, if students did not understand, they would ask questions and the teacher would give feedback directly to students. From the seventh question, it can be seen that the influence of the initiation carried out by the teacher on the students. All students indicated that their English had improved as a result of the teacher encouraging them to engage in the question-and-answer session, which was corroborated by observations made during classroom spoken talk. The eighth question about the influence of the IRF pattern on improving students' English, said that the initiation was given, student responses and feedback from the teacher had a positive impact on the student's English.

Through these observations and interviews, the interaction between teachers and tenth-grade students at the research site occurred at the beginning of the learning and teaching process, for example, when the teacher greeted the students. The teacher posed some questions to the students at the start of class. The teacher's main question was addressed to all students. Some students enthusiastically responded to the teacher's initiation. When the teacher initiated the students with some questions, they could answer the questions well. This situation reflected that students paid attention to the teacher and learning activities in the classroom. After that, the question and answer activity had several objectives. This activity was designed to introduce students to the lesson's topic, maintain students' attention from the start of the lesson, keep students active during the teaching and learning process, and verbally convey what was on their minds.

The interaction between teachers and students in the classroom occurred in question-and-answer activities when they discussed the material together in the teaching and learning process. Question and answer activities could make students think actively. They were ready to follow the teaching and learning process of English because they knew what they were going to learn. Questions and answers also helped students to stay focused on the teaching and learning process. Their concentration was maintained from the start when discussing the material. The students had pay attention and concentrate on the teaching and learning process because they had to answer questions from the materials.

Teachers who give questions randomly to students make students concentrate on question and answer activities. They tend to listen to the teacher's questions carefully. They can answer the teacher's questions well. They seem more courageous in expressing their ideas, opinions, and feelings. In addition, their self-confidence also appears when they answer the teacher's questions. Thus, students' responses show their interest in the teaching and learning process. Students are communicative in responding to the teacher. During this activity, the teacher balanced the interaction between the teacher and students by providing feedback to students according to the responses given by the teacher.

Researcher: "Then when Mam Ria asks questions about the lessons you are studying and providing corrective responses from your answers, what kind of impact does it have on your English?” 


\section{IRJE | Indonesian Research Journal in Education | | Vol. 5 | No. 2| December|Year 2021|}

Student 1: "hmm very influential, ma'am ria provides improvements if we don't understand, we become more understanding about English. Maybe even more, we can learn a lot from these improvements."

Student 2: "have a positive impact."

Student 3: "So it seems like I understand better because if it's wrong, it must be corrected so that it has a positive impact."

Student 4: "Of course it will increase."

Student 5: "Have a positive impact on our English."

Student 6: "So we know more about our mistakes so we can fix them faster."

This is supported by the findings of interviews, which showed that students believed that questions and answers and teacher feedback helped them improve their English because they could learn from their mistakes and immediately corrected them based on the teacher's feedback as they added new vocabulary.

\section{Discussion}

One of the most crucial parts of establishing active communication between teachers and students in the classroom is classroom interaction. In our study, an aspect used to assess the interaction between IPA 5 and X IPA 4 classes was the IRF Pattern in the classroom. In this case, the IRF pattern revealed that the teacher dominated the classroom during the lesson, which was the study's first objective. While some students actively participated in question and answer sessions, others did not react to the teacher's initiation. This result is similar to previous studies, which found that (e.g., Rahmi et al., 2008; Rashidi \& Rafieerad, 2010), the teacher still dominated the interaction during the lesson, even though the IRF pattern was trying to be applied in the classroom. However, other research informed that in line with the type of IRF pattern, in the classroom activities the student's response was dominantly occurred (Rustandi \& Mubarok, 2017). In other words, in terms of dominating, it depends on what subject matter is presented in the classroom and how the teacher tries to make students active in the classroom. If the subject matter in class is easy enough, student participation will often occur. On the other hand, if the teacher's way of provoking students by initiating can make them interested, the percentage of student responses will increase.

The findings of the second research objective, even if the class was dominated by the teacher, interviews with six students using the IRF pattern on the teacher-student interaction process revealed that students might still improve their English. Students were asked whether the teacher's question and answer session had an effect on their English, and they responded that their English had improved. Students demonstrated that they were still trying to answer questions during class observations, despite the fact that the teacher dominated each class observation.

The conclusions of this study contradict those of previous studies conducted by Waliyani and Yuliani (2018) at the same school but in a different year, the students were very passive and complained a lot because of a lack of confidence. According to interviews conducted when students were asked about activity in the classroom. 


\section{IRJE | Indonesian Research Journal in Education | | Vol. 5 | No. 2| December|Year 2021|}

$\begin{array}{lll}\text { Researcher } & : & \text { "Do you like being active in the classroom?" } \\ \text { Student } 1 & : & \text { "Sometimes I am also active; miss if I understand the materials } \\ \text { Student } 2 & : & \text { "Active" } \\ \text { Student } 3 & : & \text { "If the teacher asks a question, I will answer it." } \\ \text { Student } 4 & : & \text { "Active if during the question session." } \\ \text { Student } 5 & : & \text { "Not really." } \\ \text { Student } 6 & : & \text { "Active." }\end{array}$

Although the teacher dominated the interaction in the classroom, some students played an active role in question-and-answer sessions. Researchers conducted classroom observations. This research was conducted during the COVID-19 pandemic. So starting from one year ago until the research ended in March, the school was still in the Covid 19 pandemic that students were doing lessons online. Some of the limitations of this study also slightly interfere with teaching and learning process. Classroom observations were done by online learning. Teacher and students used google classrooms during the interaction. Students also did not activate the camera because the teacher said that the students complained about the internet cost being less than activating the camera. Badr (2017) proposed that despite the fact that although the researchers recognized the importance of recording teachers' expressions and body movements because they played a critical role in monitoring classroom spoken language, and that such expressions and body movements can only be recorded using video-recording devices, the researchers were unable to use such video-recording devices as research instruments because the class teacher was concerned about data misuse. As a result, the researchers had chosen to reject the teacher's concerns and anxiety by attending class with an audio recorder. In this aspect, the researchers realized that this strategy was not optimal for recording nonverbal interactional events that commonly occurred during classroom talks but argued that it is better than doing nothing at all.

\section{Conclusion, Implications, and Recommendation}

This article aimed to report on the use of the IRF pattern on students' classroom interactions and the impact of the IRF pattern in improving students' English. There were two techniques were used to find the purpose of this research such as classroom observation and interviews. Classroom observation was used to determine the dominant IRF Pattern in the classroom observation between teacher and student. The findings from class observations revealed that the IRF pattern occurred during classroom spoken discourse, but the most of the interactions made by the teacher only asked questions and students answered them in the learning process sequentially. The teacher only gave questions and students did not answer many questions because classroom interaction was related to the 2013 curriculum which emphasizes student dominance in the classroom.

Interviews were employed to respond to the questions posed by the second research question. Although teacher interaction dominated the classroom, the interviews demonstrated that students' English had improved. When the teacher asked questions in the style of English lessons, the majority of students remembered the sentences and attempted 


\section{IRJE | Indonesian Research Journal in Education | | Vol. 5 | No. 2| December|Year 2021|}

to participate actively. When teaching the topic, the teacher constantly provided examples, which helped the students understand it better.

The study's findings suggest that English teachers ask too many questions without knowing if students could accept them, that the material presented was always the same, and that there was no substantial change. The teacher was required to give feedback, which ensured that students were satisfied with the teacher's responses. If this was not done, students' creativity might be stifled, and they might become less interested in asking questions. When doing classroom activities, teachers had employed some innovative methods or techniques. In relation to that, some recommendations are offered. First, the teachers of English need to understand what questions students need to ask, so that students can respond well because it must be in line with the 2013 curriculum, which places students as the center of learning. Second, teachers need to use more varied feedback from the IRF pattern. It can be seen from the observation that the teacher does not use feedback too much when students respond to the initiation from the teacher because feedback is very important to increase student motivation, confidence, and evaluation. Third, for further research, there are several aspects that the next researchers might be able to do. Further researchers can use the theory of Sinclair and Coulthard (1992) in the IRF pattern to see the interactions between students and group members, other English teachers, or use the best interaction practices in analyzing interactions between teachers and students in the classroom in improving students' English.

\section{Disclosure Statement}

This study does not include any defamatory questions. The authors state that they have no conflicting interests in this study or the publishing of this paper.

\section{Acknowledgments}

I would like to thank Sriwijaya University for providing facilities and opportunities to develop this research and Mrs. Machdalena Vianty, M.Ed., M.Pd., Ed.D as the first advisor and also Mrs. Sary Silvhiany, M.Pd., M.A., Ph.D. as my second advisor. Then I would like to thank SMA Muhammadiah 1 Palembang for allowing me to do this research.

\section{References}

Abrar, M., Mukminin, A., Habibi, A., Asyrafi, F., Makmur, M., \& Marzulina, L. (2018). "If our English isn't a language, what is it?" Indonesian EFL Student Teachers' Challenges Speaking English. The Qualitative Report, 23(1), 129-145. Retrieved from http://nsuworks.nova.edu/tar/vol23/iss1/9

Badr, M. (2017). Exploring the impact of classroom interactional discourse on preparatory students' oral production of the target language. International Journal of Applied Linguistics \& English Literature, 8(1), 178-185. http://dx.doi.org/10.7575/aiac.ijalel.v.8n.1p.178 


\section{IRJE | Indonesian Research Journal in Education | | Vol. 5 | No. 2| December|Year 2021|}

Brown, H. D. (2000). Principles of language learning and teaching (4th ed). New York: Wesley Longman, Inc.

Brown, H. D. (2001). Teaching by principles: an interactive approach to language pedagogy (2nd ed). New York: Addison Wesley Longman, Inc.

Creswell, J. W. (2012). Educational research: Planning, conducting and evaluating quantitative and qualitative research (4th ed.). Boston: Pearson.

Lauder, A. (2008). The status and function of English in Indonesia: a review of key factors. Sosial Humaniora, 12 (1), 9-20.

Lin, A. (2007). What's the use of "Triadic dialogue": Activity theory, conversation analysis and analysis of pedagogical practices. Pedagogies: An International Journal, 2 (2), 77-94. https://doi.org/10.1080/15544800701343943.

Liu, Y. (2008). Teacher-student talk in Singapore Chinese language classrooms: a case study of initiation/response/follow up (IRF). Asia Pacific Journal of Education, 28(1), 87-102. https://doi.org/10.1080/02188790701850071.

Lyle, S. (2008). Dialogic teaching: Discussing theoretical contexts and reviewing evidence from classroom practice. Language and Education, 22(3), 222-240. https://doi.org/10.1080/09500780802152499

Kothari, C.R. (2004). Research methodology methods and techniques second revise edition. New Delhi: New Age International Publishers.

Mackey, A. (2012). Input, interaction and corrective feedback in L2 learning. Oxford: Oxford University Press.

Markee, N. (2005). Conversation analysis for second language acquisition. In E. Hinkel (Eds.), Handbook of research in second language teaching and learning (pp. 355-374). Mahwah, NJ: Lawrence Erlbaum.

Mappiasse, S.,S \& Sihes, B., J. (2014). Evaluation of English as a foreign language and its curriculum in Indonesia: A review. English Language Teaching, 7(10), http://dx.doi.org/10.5539/elt.v7n10p113

McCarthy, M. (2002). Discourse analysis for language teachers. Cambridge: Cambridge University Press.

Mehan, H. (1979). Learning lessons: Social organization in the classroom. Harvard University Press.

Menegale, M. (2008). Expanding Teacher-Student Interaction through More Effective Classroom Questions: From Traditional Teacher-Fronted Lessons to Student-Centred Lessons in CLIL. Italy: $\quad$ Ca' Foscari University of Venice.

Miles, B.A., Huberman, M,A., \& Saldana, J. (2014). Qualitative data analysis: A methods sourcebook (3th ed). New Delhi: Sage Publications.

Myhill, D. (2006). Talk, talk, talk: Teaching and learning in whole class discourse. Research Papers in Education, 21(1), 19-41. https://doi.org/10.1080/02671520500445425

Paterson, D. (2008). Analysing classroom discourse using the Sinclair/Coulthard model. Studies in Language and Literature, 2 (8) 1, 68-94

Rachel. (2016). Teacher-students' interaction patterns in English class for the tenth grade students of SMA Negeri 1 Mengkendek. TEFL Overseas Journal, 4(1).

Rashidi, N., \& Rafieerad, M. (2010). Analyzing patterns of classroom interaction in EFL classrooms in Iran. The Journal of Asia TEFL, 7(3), 93-120. 


\section{IRJE | Indonesian Research Journal in Education | | Vol. 5 | No. 2| December|Year 2021|}

Rahmi, A., Amri, Z., \& Narius, D. (2018). An analysis of irf (initiation-response feedback) in interaction between teacher and students in English class at sma negeri 2 Padang Panjang. Journal of English Language Teaching, 7(3), 415-425.

Richard, J.C. et.al. (2002). Longman dictionary of language teaching and applied. New York: Pearson Education Limited.

Richards, J. C., and Lockhart, C. (1996). Reflective teaching in second language classrooms. Cambridge: Cambridge University Press.

Rido, A., Ibrahim, \& N., Nambiar, K. M. (2014). Investigating master teacher's classroom interaction strategies: a case study in Indonesian secondary vocational school. Procedia - Social and Behavioral Sciences, 118 (14), 420 - 424. https://doi.org/ 10.1016/j.sbspro.2014.02.057

Rustandi, A., Mubarok, H. A. (2017). Analysis of IRF (Initiation-Response-Feedback) on classsroom interaction in EFL speaking class. Journal of English Education, Literature, and Culture, 2(1), 239-250.

Sinclair, J and Coulthard, M. (1992). Toward An Analysis of Discourse. Malcolm Coulthard (Ed.), Advances in Spoken Discourse Analysis (pp. 1-34). London: Routledge.

Sundari, H.(2017). Classroom Interaction in Teaching English as Foreign Language at Lower Secondary Schools in Indonesia. Advances in Language and Literary Studies,

6 (8), 2203-4714, http://dx.doi.org/10.7575/aiac.alls.v.8n.6p.147

Walsh, S. (2006). Investigating classroom discourse. London: Routledge.

Waliyani \& Yuliani, S. (2018). Improving students' speaking skills through demonstration method of the class xi ips 1 students of SMA Muhammadiyah 1 Palembang.

English Community Journal, 2 (2), 262-268.

Wasiah, N. (2016). A study of teacher talk in classroom interaction at an Islamic senior high school. OKARA Journal of Languages and Literature, 1(1), 29-43.

Wolcott, H. (2008). Ethnography: A way of seeing (2nd ed.). Walnut Creek: Altamira.

Willis, D. (1992). Caught in the act: using the rank scale to address problems of delicacy. New York, NY: Routledge.

\section{Biographical Notes}

EKA BARAHMA PUTRI is a M.Pd. student from English Education Department, Faculty of Teacher Training and Education, Sriwijaya University, Indonesia.

MACHDALENA VIANTY, M.Ed,. M.Pd., Ed.D is a Doctor of Education from English Education Department, Faculty of Teacher Training and Education, Sriwijaya University, Indonesia.

SARY SILVHIANY, M.Pd., M.A., Ph.D is an Assistant Professor from English Education Department, Faculty of Teacher Training and Education, Sriwijaya University, Indonesia. 